\title{
O conflito entre o que é literatura e o que é teologia a recepção de $O$ Código Da Vinci
}

\author{
Elaine Reis
}

\section{SciELO Books / SciELO Livros / SciELO Libros}

FERRAZ, S., et al.,orgs. Deuses em poéticas: estudos de literatura e teologia [online]. Belém: UEPA; Campina Grande: EDUEPB, 2008. 364 p. ISBN 978-85-7879-010-3. Available from SciELO Books $<\underline{\text { http://books.scielo.org }>\text {. }}$

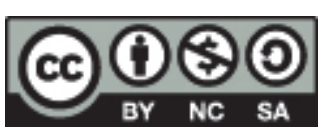

All the contents of this work, except where otherwise noted, is licensed under a Creative Commons Attribution-Non Commercial-ShareAlike 3.0 Unported.

Todo o conteúdo deste trabalho, exceto quando houver ressalva, é publicado sob a licença Creative Commons Atribuição Uso Não Comercial - Partilha nos Mesmos Termos 3.0 Não adaptada.

Todo el contenido de esta obra, excepto donde se indique lo contrario, está bajo licencia de la licencia Creative Commons Reconocimento-NoComercial-CompartirIgual 3.0 Unported. 


\section{O conflito entre o que é Li- teratura e o que é Teologia na recepção de $O$ Código Da Vinci}

Elaine Reis 


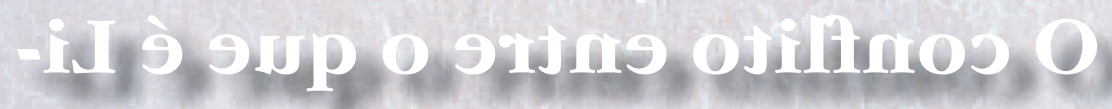

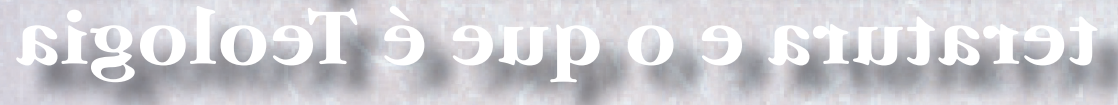

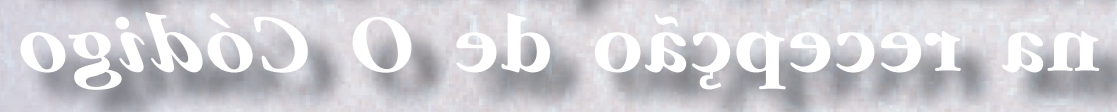
jomingol

zigr gnisole 
REIS, Elaine

"O CDV é quente, os críticos ainda mais". Manchete do New York Daily Newn (04 de setembro de 2003)

Resumo: Na esteira do lançamento de O Código Da Vinci (OCDV), foram lançados, quase que, concomitantemente, mais de 20 livros não ficcionais, que o recepcionaram. Utilizando um corpus de 10 livros receptivos, escolhidos aleatoriamente para evitar um direcionamento tendencioso da pesquisa, este artigo levanta a hipótese de que eles, ao se aproximarem de $O C D V$, texto literário e de ficção, com intuito teológico, confundem o que é teologia e o que é literatura. Imersa nessa ótica, surgem algumas perguntas: há crítica literária sobre $O C D V$ ? Como podem ser classificados os livros que acolheram a referida narrativa: são de crítica jornalística, resenhas com finalidade crítica, manuais explicativos ou são apenas livros caça-níqueis? Para respondê-las, utilizaremos como referencial teóricos autores como Blume, Franken, Eaglenton, Barthes e Piglia.

Palavras-chave: $O$ Código Da Vinci, recepção, Teologia, Literatura, crítica.

Abstract: In the wake of The Da Vinci Code (TDVC), more than 20 nonfictional books were concurrently published. A sample of 10 similar books, which were randomly chosen to avoid bias, was used in this study. This approach demonstrates that, in their theological intention, these literary and fictional texts repeatedly confuse Theology and Literature in their attempt to engage TDVC. From this perspective, some questions emerge: is there any literary criticism regarding TDVC? How can the various books inspired by TDVC be classified? Are they journalistic criticism, critical digests, instruction manuals or books written only with the aim to profit? In order to answer these questions, this tudy is underpinned by theoretical works of Blume, Franken, Eaglenton, Barthes and Piglia.

Keywords: The Da Vinci Code, concurrent releases, Theology, Literature, literary criticism..

\footnotetext{
* Mestre em Literatura pela UFSC (Universidade Federal de Santa Catarina) na linha pesquisa de Teologia e Literatura. E-mail: nanereis@hotmail.com.
} 
O Código Da Vinci ${ }^{81}$ levantou um motim contra a hipótese do casamento entre Jesus e Madalena. No seu diálogo com a Bíblia e com o Jesus bíblico, a principal acusação a Dan Brown é a afirmação contida na sua narrativa: "Todas as descrições de obras de arte, arquitetura, documentos e rituais secretos neste romance correspondem rigorosamente à realidade" (BROWN, 2003. p.9). Mesmo sendo uma obra ficcional, estes fatores se atrelam à "teorias da conspiração" 82 de tal modo, que despertam toda a polêmica em torno do livro, e servem de prefácio para as inúmeras e diversificadas opiniões que surgiram em torno de sua trama.

O romance foi traduzido para mais de cinqüenta línguas; vendeu milhões de cópias em todo o mundo; teve uma excelente campanha publicitária e um imenso sucesso mercadológico. Desde seu lançamento em 2003, vem abrindo espaço para muitas matérias jornalísticas. Seu roteiro foi vendido para Hollywood que em 2006 lançou o filme $O C D V$ com o título igual ao do livro.

Confirmando o sucesso, a narrativa inspirou muitos outros livros: uma edição especial ilustrada; o exemplar de um caderno de viagens incluindo um roteiro ilustrado; um livro sobre o filme; uma biografia não autorizada de Dan Brown; e aproximadamente 20 livros, não ficcionais, que teceram comentários e hipóteses sobre o livro.

A narrativa despertou tamanha polêmica em torno de sua trama, que muitas pessoas, ao entrarem na livraria para comprar o romance, também compram um ou mais desses mencionados livros que, em sua maioria, se oferecem como "decodificadores" de OCDV.

Este artigo explora essa estrondosa onda de lançamentos, utilizando um corpus de 10 livros comentadores de $O C D V$, escolhidos aleatoriamente para evitar um direcionamento tendencioso da pesquisa. ${ }^{83}$

Analisando esse corpus, levantamos a hipótese que, ao se aproximarem de $O C D V$, texto literário e de ficção, confundem o que é Teologia e o que é Literatura. Imersa nessa ótica, surgem perguntas como: há 81 Para o presente trabalho utilizaremos a tradução de Celina Cavalcante, impressa na cidade do Rio de Janeiro em 2004, edição da Sextante. E para a citação utilizaremos a partir daqui a sigla $O C D V$ - todos os negritos são de nossa autoria.

82 Teoria da conspiração é uma teoria que supõe que um grupo de conspiradores está envolvido num plano e suprimiu a maior parte das provas desse mesmo plano e do seu envolvimento nele. No caso de $O C D V$, o principal plano é ocultar um segredo milenar da Igreja Católica: Jesus e Maria Madalena foram casados e tiveram filhos. Para maiores informações vide http://pessoas.hsw.uol.com.br/teorias-da-conspiracao.htm.

83 Os títulos do corpus analisado constam também na bibliografia. 
crítica literária sobre $O$ Código Da Vinci? Como podem ser classificados os livros que acolheram a referida narrativa: são de crítica jornalística? Resenhas com finalidade crítica? Manuais explicativos? Ou são apenas livros caça-níqueis?

Antes de respondermos a essas perguntas, apresentamos as reações que os 10 livros expressaram ao $O C D V$. Dividimos os livros em duas categorias: os moderados, que apresentam suas reservas e defesas ao romance com um tom ponderado e sem partidarismo exacerbado; e os radicais, que com discurso cristão se ofendem com o romance e o atacam, o acusam, o condenam e freqüentemente o comparam com a Bíblia.

\section{Os moderados}

No livro A verdade por trás de O Código da Vinci: uma Resposta desafiadora à Ficção mais Vendida ${ }^{84}$, publicado em 2005, Richard Abanes promete desvendar o que ele chama de bases turvas, para então desmascarar a aparente historicidade que o romance de Dan Brown assume:

$\mathrm{O}$ assunto é fato contra ficção. Verdade contra mentiras. Precisão contra imprecisão. (ABANES, 2005. p. 107) $)^{85}$.

A contradição do título do livro dá margens para pensarmos que Abanes não entendeu que se trata de ficção, e discorrermos sobre o fato de que ele não deveria ter escrito nem o título e nem o livro.

$O$ equívoco se fortalece a cada virada de página quando o autor contesta $O C D V$ com a frase que dá título ao livro. Nota-se a obsessão do autor pela verdade, que na sua voz, é ferida pelo romance de Brown. Epígrafes que ressaltam o amor à verdade iniciam, terminam e são distribuídas por todo o livro. Entretanto o mais preocupante para o autor é:

(...) a apropriação indevida de algumas figuras centrais da igreja cristã com o intuito de validar sua teoria de conspiração: especificamente Maria Madalena e Jesus Cristo. (ABANES, 2005. p. 45).

Para Abanes a principal fraqueza do romance é a falta de precisão

84 Negrito nosso

85 Todos os negritos são de nossa autoria. 
em questões fundamentais como a apresentação dos fatos históricos e de crenças religiosas como o cristianismo e o gnosticismo, e a interpretação de obras de arte. Segundo o autor, Dan Brown insulta a obra e a vida de Leonardo da Vinci. (ABANES, 2005. p. 105).

Estando claro que $O D C V$ pertence ao campo da literatura e dado sua classificação de romance, qualquer separação de fato contra ficção, verdade contra mentira, precisão contra imprecisão, é equivocada e não se justifica.

Através do livro As chaves do Código Da Vinci: A descendência secreta de Jesus e outros mistérios, publicado em 2004, L. F. Bueno e M. F. Urresti intencionam investigar, minuciosamente e sem partidarismo, as teorias nas quais Dan Brown se baseia para escrever seu romance; oferecem "as chaves" para que o leitor faça a distinção entre verdade e especulações.

Os autores elogiam a maneira inteligente com que Brown soube dosar as informações. Além disso, analisam várias contradições bíblicas, confirmam muitas coincidências que sustentariam $O C D V$ e questionam as histórias que ao longo dos séculos vem sendo contadas sobre Jesus Cristo. Para assegurar que o Jesus que conhecemos teve uma "biografia adaptada ao seu papel de messias", afirmam:

Um ser que nasceu para sofrer com os pecados da humanidade e cuja existência pode ter sido um pouco diferente do que narram as Sagradas Escrituras. Evidentemente são especulações, mas há um ditado que diz que onde há fumaça, há fogo, e, neste caso, há muita fumaça (...). (BUENO \& URRESTI, 2004. p. 17)

O livro ainda expõe comentários sobre o romance, para demonstrar que ele despertou inflamadas polêmicas e sentimentos contraditórios: muitas críticas que tentam "desmentir" seus argumentos e poucos elogios.

Ainda que concordem que o romance é um livro de ficção que mexe com referências religiosas de milhares de pessoas no mundo, os autores se contradizem quando defendem $O C D V$ e afirmam que Dan Brown tem razão ao duvidar da história que o Novo Testamento relata.

Bueno e Urresti apropriam-se de $O C D V$ como pretexto para fazer análise e indagações sobre as contradições que a Igreja tem apresentado à profissão de fé, por conta de dúvidas, vacilações e lacunas deixa- 
das pela Bíblia. É assim que, mesmo sutilmente, tratam o romance de Brown, não apenas como ficção, mas como um livro que questiona e comprova que a Igreja mentiu e impôs um pensamento único sobre Jesus.

Em Decifrando O Código Da Vinci: os fatos por trás da ficção, ${ }^{86}$ publicado em 2005, Simon Cox, separa e responde, literalmente de A a $\mathrm{Z}$, o que há de verdadeiro e de ficção no romance. Longe de fazer apologia ou de condenar à narrativa, o autor se mantém imparcial ao longo de todo o livro.

Poderíamos caracterizá-lo apenas como manual explicativo que cumpre o objetivo ao qual se propõe na introdução "Se você está em busca de um livro que condene Brown e o seu romance escolheu a literatura errada" (COX, 2005. p. 12), não fosse a grande contradição: se é romance a distinção de "verdadeiro e fictício" é descabida.

No livro Os Segredos do Código, Dan Burstein explica que se sentiu intelectualmente desafiado pelo $O C D V$; por qual motivo despertou tanto o interesse do público e porque é tão sintonizado com o espírito contemporâneo. Desejou saber o que era fato e o que era ficção na narrativa.

Seu livro é apresentado como um guia explicativo sobre as questões levantadas pelo romance e compila mais de sessenta artigos extraídos de livros, sites, ensaios e entrevistas sobre os temas abordados em $O C D V$. Estes textos são variados: respondem a muitas perguntas a respeito do livro, apresentam erros, falhas e detalhes, elogios, etc.

Para Burstein está claro que a obra é um romance, mas, ele expõe que, as idéias por trás de seus temas lhe parecem válidas e bem fundamentadas. E a respeito da questão "fato versus ficção" conclui:

Minha conclusão pessoal é de que o CDV é uma fascinante e bem elaborada obra de ficção, construída, do começo ao fim, com interessantes partículas de fatos pouco conhecidos e provocações estimulantes, mesmo que fortemente especulativas. (BURSTEIN, 2004. p. 24).

$\mathrm{O}$ autor não se compromete tanto, porque apresenta textos diversificados e de vários autores. Porém, ao almejar conhecer o que é fato e o que é ficção na narrativa e exibir textos com a intenção de debater este tema, acaba se equivocando tanto quanto aos outros livros aos quais já nos referimos.

86 Negrito nosso. 
Em Revelando o Código da Vinci, publicado em 2005, Martin Lunn garante que o livro foi feito para leitores que buscam a verdade, esteja ela onde estiver. Para isso o autor promete mostrar a verdade por trás da pesquisa de Brown, separando a realidade da ficção.

Ao fazer a separação proposta, Lunn não toma partido a favor ou contra $O C D V$, não faz ataques ao romance e utiliza um tom bastante sutil e ponderado.

Por um lado o autor se abstém de dar qualquer opinião comprometedora a respeito do romance, se quer apresenta uma conclusão de seu livro. Em contrapartida, Lunn forma opinião a respeito de aspectos da ficção de Brown, como por exemplo, quando ele concorda e explica que Jesus tenha sido casado.

\section{Os radicais}

No livro A fraude do Código Da Vinci - toda a verdade sobre a ficção do momento ${ }^{87}$, o teólogo Ervwin Lutzer propõe-se a alertar o leitor sobre as "inverdades" afirmadas por Dan Brown e revelar a verdadeira história que existe no romance. Defende ainda a historicidade do cristianismo e da pessoa de Jesus.

Nota-se na palavra "fraude" expressa no título do livro, a tendência em confundir-se relato factual e ficção. Isso se comprova logo nas linhas inicias, quando Lutzer começa analisando $O C D V$ procurando dar "respostas dignas" a questões sobre a vida de Jesus. (LUTZER, 2004. p. 21).

Entretanto, são nos últimos capítulos que o autor esquece a análise a que se propunha e através de um discurso dogmático e teológico cristão, exalta o Cristianismo e propõe um encontro com Deus. Após desafiar o leitor incrédulo a provar que a Bíblia mente, ele juramenta:

Se você, como eu, crê na Bíblia posso assegurarlhe que não temos nada a temer com essas especulações subjetivas. (LUTZER, 2004. p. 109).

Desconsiderando totalmente que $O C D V$ é um livro de ficção, Lutzer o trata como um ensinamento que concorre com o ensinamento religioso cristão, propõe que devemos confiar no Jesus da Bíblia e nas palavras de Deus, não no Jesus de $O C D V$ e nas palavras de Brown. (LUTZER, 2004. p. 127).

87 Negrito nosso. 
Com seu discurso cristão e ameaçador, o autor demoniza Dan Brown, trata-o quase como o "tentador" encarnado, tentando desvirtuar os fiéis dos caminhos do cristianismo. E prega sua palavra, advertindo o leitor para que ele não seja um pecador, para que não escolha a mentira, não creia no $O C D V$ e sim na Bíblia.

Também por esse viés, em Decodificando Da Vinci: os fatos por trás da ficção de O Código Da Vinci ${ }^{88}$, publicado em 2004, e que também apresenta problemas contraditórios no título do livro, Amy Welborn diz tê-lo escrito para ajudar os leitores a examinar as questões interessantes de $O C D V$. Entretanto ela é pouco tolerante com a ficção de Brown e não o considera como fonte digna de crédito (WELBORN, 2004. p.21). Nota-se aqui o equívoco de Welborn, pois sendo ficção, o livro não tem que ser digno de crédito.

A autora pretende elaborar uma tarefa dantesca: cobrir parte da atividade teológica que diz respeito ao cânone e também à natureza humana e divina de Jesus, com o propósito de explorar a verdade por trás de $O C D V$. Igualmente, é intenção da autora, esclarecer e corrigir os erros surpreendentes relacionados à religião, história e arte, e também rever ensinamentos cristãos desenvolvendo a compreensão das raízes históricas da autenticidade da fé cristã:

(...) por querer ensinar história dentro da estrutura da ficção é que ele não é "apenas um romance" (WELBORN, 2004. p.24).

Já no primeiro capítulo a autora dá indícios de que o romance tende a ser concorrente da Bíblia, e a partir daí, apregoa todo o tempo que devemos dar mais crédito ao Novo Testamento do que às alegações de $O C D V$. Ela convida o leitor, ao invés de levar a sério as afirmações de Brown, a buscar a verdade no Novo Testamento:

Está curioso com relação a Jesus? A verdade está tão perto quanto o livro que está na sua estante. $\mathrm{E}$ não, não é $O$ Código da Vinci. Não deixe que um romancista que está na moda instrua você nos caminhos da fé. Volte para o começo e dirija-se à fonte: pegue a Bíblia. Você pode ficar surpreso com o que vai encontrar. (WELBORN, 2004. p.136).

Welborn termina seu livro com um sotaque religioso, catequizador, com tom mais oracular, parenético do que argumentativo, faz com 88 Negrito nosso. 
que seu texto esteja mais próximo de sermão do que propriamente crítica literária.

O livro Desmascarando O Código Da Vinci ${ }^{89}$, publicado em 2004, se apresenta como a tão esperada resposta para as perguntas que possam estar incomodando os leitores e trás a proposta de desmascarar a "motivação oculta" de Brown, que é uma poderosa forma de propaganda religiosa: a espiritualidade da Nova Era:

Na sua essência $O$ Código Da Vinci é uma redefinição radical de Deus como a força impessoal da natureza. (GARLOW \& JONES, 2004. p.214).

Com o propósito cristão e discursos de fé, afirmam que Brown manipula a realidade e que por isso seu código é muito perigoso para a alma. Durante todo o livro é feita uma estudo comparativo entre $O C D V$ e a Bíblia. Já nas primeiras páginas há a sugestão de que devemos fazer a leitura do livro acompanhados de um exemplar de $O C D V$ e de uma Bíblia. Está claro que o leitor está diante de uma escolha. A opção que deve ser tomada é óbvia, pois escolher $O C D V$ é servir ao diabo:

Depois de sua conversão ao cristianismo, Bob Dylan cantou em outra música: Você terá de servir alguém, (...) pode ser o diabo ou pode ser o Senhor". O Código Da Vinci e o livro que você está lendo agora mostram a escolha que cada pessoa tem de fazer. É a mesma escolha que Elias colocou diante do povo de Deus: "Até quando vocês vão oscilar para um lado e para o outro? Se o SENHOR é Deus, sigam-no "(1Reis 18.21). (GARLOW \& JONES, 2004. p.218).

Os autores almejam separar fatos de ficção para "desmascarar" $O C D V$. No entanto se contradizem ao criarem um novo gênero para o romance "O livro de Brown não é nem fato nem ficção. É uma fa-cção isto é, uma narrativa astuta que mistura fatos restritos com algumas afirmações grosseiramente exageradas" (GARLOW \& JONES, 2004. p.42).

Darrell L. Bock, autor de Quebrando O Código Da Vinci: respostas às perguntas que todos estão fazendo ${ }^{90}$, publicado em 2004, considera $O C D V$ um livro de ficção que é "quase não - ficção", ou uma quase ficção. Para ele, o romance estaria implantado num gênero próprio, por apresentar: "confusa categoria de ficção histórica, onde 
a idéia é a de que, apesar de ser um romance, a história é um fato" (BOCK, 2004. p. 22).

A partir de oito capítulos, Bock intenciona desmascarar os fatos apresentados pela narrativa, ou melhor, "quebrar" os códigos do livro, desmentindo, uma a uma, as "falsas afirmações" do romance, alegando que Brown mergulhou fundo na ficção, e também na má pesquisa histórica.

As declarações de Bock são bastante contraditórias, pois, como ele mesmo afirma, o livro é uma ficção, e sendo assim, não existem falsas afirmações, tampouco má pesquisa histórica. Para instituir o argumento central de seu livro, Bock afirma:

(...) a maior parte do que está na base deste megacódigo carece de fundamentação histórica. Ao quebrar $O$ Código da Vinci, descobrimos que há muito mais acontecendo aqui do que a simples criação de um romance de ficção. Existe uma revisão do que foi e é o cristianismo. (BOCK, 2004. p. 162).

Ao concluir seu livro, quebra $O C D V$ e institui o código de Jesus, que segundo ele, é o verdadeiro código e "É algo em que vale a pena acreditar" (BOCK, 2004. p. 182).

Nessa mesma linha de raciocínio, em $\underline{\text { Rough Guide - O Código da }}$ Vinci: História - personagens e lugares, publicado em 2004, seus autores discutem as principais questões da ficção de Brown, oferecem seu livro como guia de viagem para os cenários que o romance apresenta $\mathrm{e}$ levantam as seguintes perguntas: Em que medida a mensagem da narrativa é verdadeira? Será que o livro se julga mais que ficção?

No decorrer das páginas os autores pretendem desvendar "a verdade histórica segundo Dan Brown", desmentindo o autor e empregando termos que confirmam: a mentira é de Dan Brown.

Michael e Verônica entram em contradição no momento em que, mesmo considerando o livro ficção, levantam perguntas a respeito da veracidade da mensagem da narrativa. Além disso, talvez não sejam os leitores que ficam em dúvida sobre este aspecto, mas os pretensos críticos.

Os autores também se valem de muitas frases irônicas para esclarecer as alegações do romance, advertindo que não se deve usá-lo como guia turístico, por ele conter, "becos sem saída e sérias anoma- 
lias". Portanto, Dan Brown "não é alguém a quem possamos pedir orientação nas ruas".

Evidencia-se que os livros aqui analisados têm interpretado mal $O C D V$ sob quase todos os pontos de vista. Os moderados, mais condescendentes, mas sem deixar de confrontar fato versus ficção, verdade versus mentiras, precisão versus imprecisão; os radicais, compromissados com suas convicções religiosas, atacam, excomungam $O C D V$ e seu autor com discurso dogmático, teológico-cristão, convidam, ou melhor, apelam à espiritualidade do leitor, colocando-o diante de uma escolha: a verdade, o bem, o fato, ou seja, a Bíblia; a encarnação do mal, a mentira, a "fa-cção", ou seja, $O C D V$.

\section{O tribunal de Julgamento}

Dado tais evidencias, organizamos uma tabela intitulada $O$ tribunal de julgamento, que mostra de forma mais sintética as principais acusações que o corpus analisado faz ao romance de Dan Brown:

\begin{tabular}{|c|c|c|c|c|c|}
\hline \multicolumn{6}{|c|}{ O TRIBUNAL DE JULGAMENTO } \\
\hline Título & Modera- & Radical & Autor & Profissão & Principais Acusações \\
\hline $\begin{array}{l}\text { A fraude do } \\
\text { Código Da } \\
\text { Vinci: toda a } \\
\text { verdade sobre } \\
\text { a ficção do } \\
\text { momento }\end{array}$ & & $\mathbf{X}$ & $\begin{array}{l}\text { Ervwin } \\
\text { Lutzer }\end{array}$ & $\begin{array}{l}\text { Pastor, Bel. } \\
\text { em Artes, } \\
\text { Ms. em } \\
\text { Teologia } \\
\text { e Dr. em } \\
\text { Direito. } \\
\end{array}$ & $\begin{array}{c}\text { Herético; preocupante; } \\
\text { obsceno; ataca a fé - } \\
\text { cristã, a Igreja e Jesus } \\
\text { Cristo; demoniza Dan } \\
\text { Brown. }\end{array}$ \\
\hline $\begin{array}{l}\text { A verdade por } \\
\text { trás de O Có- } \\
\text { digo da Vinci: } \\
\text { uma Resposta } \\
\frac{\text { desafiadora }}{\text { â Ficcão mais }} \\
\text { Vendida }\end{array}$ & $\mathbf{X}$ & & $\begin{array}{l}\text { Richard } \\
\text { Abanes }\end{array}$ & $\begin{array}{l}\text { Escritor e } \\
\text { jornalista. }\end{array}$ & $\begin{array}{c}\text { Fere a verdade Cristã; } \\
\text { valida a teoria de cons- } \\
\text { piração; insulta a obra } \\
\text { e a vida de Leonardo } \\
\text { da Vinci. }\end{array}$ \\
\hline $\begin{array}{l}\text { As chaves } \\
\text { do Código } \\
\text { Da Vinci: A } \\
\text { descendência } \\
\text { secreta de } \\
\text { Jesus e outros } \\
\text { mistérios } \\
\end{array}$ & $\mathbf{x}$ & & $\begin{array}{l}\text { *L.F. } \\
\text { Bueno } \\
* \text { M.F. } \\
\text { Urresti }\end{array}$ & $\begin{array}{l}\text { Ambos são } \\
\text { jornalistas } \\
\text { e radialis- } \\
\quad \text { tas. }\end{array}$ & $\begin{array}{l}\text { O romance não é } \\
\text { apenas ficção, pois } \\
\text { questiona e comprova } \\
\text { que a Igreja mentiu e } \\
\text { impôs um pensamento } \\
\text { único sobre Jesus. }\end{array}$ \\
\hline $\begin{array}{l}\text { Decifrando } \\
\text { O Código Da } \\
\text { Vinci: os fatos } \\
\text { por trás da } \\
\text { ficção } \\
\end{array}$ & $\mathbf{X}$ & & $\begin{array}{l}\text { Simon } \\
\text { Cox }\end{array}$ & $\begin{array}{l}\text { Editor } \\
\text { chefe de } \\
\text { revista e } \\
\text { escritor. }\end{array}$ & $\begin{array}{c}\text { Responder o que há de } \\
\text { verdadeiro e de ficção } \\
\text { no romance. }\end{array}$ \\
\hline
\end{tabular}




\begin{tabular}{|c|c|c|c|c|c|}
\hline $\begin{array}{c}\text { Decodifican- } \\
\text { do Da Vinci: } \\
\text { os fatos por } \\
\text { trás da ficção } \\
\text { de O Código } \\
\text { Da Vinci }\end{array}$ & & $\mathbf{x}$ & $\begin{array}{l}\text { Amy Wel- } \\
\text { born }\end{array}$ & $\begin{array}{l}\text { Ms. em } \\
\text { História, } \\
\text { colunista } \\
\text { redatora e } \\
\text { escritora. }\end{array}$ & $\begin{array}{l}\text { Não é apenas um } \\
\text { romance; concorre com } \\
\text { a Bíblia; visão histórica } \\
\text { leviana. }\end{array}$ \\
\hline $\begin{array}{c}\text { Desmascaran- } \\
\text { do o Código } \\
\text { da Vinci }\end{array}$ & & $\mathbf{x}$ & $\begin{array}{l}\text { Garlow } \\
\text { Jones }\end{array}$ & $\begin{array}{c}\text { Ambos são } \\
\text { Ms. em Te- } \\
\text { ologia e em } \\
\text { Divindade; } \\
\text { Ph.D.em } \\
\text { teologia; } \\
\text { Garlow é } \\
\text { pastor e } \\
\text { radialista. }\end{array}$ & $\begin{array}{l}\text { O livro é uma fa-cção; } \\
\text { propaganda religiosa da } \\
\text { Nova Era; paganismo } \\
\text { clássico; neopagão, } \\
\text { redefinição radical de } \\
\text { Deus; concorrente da } \\
\text { Bíblia; demoniza Dan } \\
\text { Brown. }\end{array}$ \\
\hline $\begin{array}{l}\text { Os Segredos } \\
\text { do Código }\end{array}$ & $\mathbf{X}$ & & $\begin{array}{l}\text { Dan Burs- } \\
\text { tein }\end{array}$ & $\begin{array}{l}\text { Jornalista } \\
\text { do New } \\
\text { York Times } \\
\text { e roman- } \\
\text { cista }\end{array}$ & $\begin{array}{l}\text { Debate e contesta fato } \\
\text { versus ficção. }\end{array}$ \\
\hline $\begin{array}{l}\text { Quebrando } \\
\text { O Código } \\
\text { Da Vinci: } \\
\text { respostas às } \\
\text { perguntas que } \\
\text { todos estão } \\
\text { fazendo }\end{array}$ & & $\mathbf{X}$ & $\begin{array}{l}\text { Darrell L. } \\
\text { Bock }\end{array}$ & $\begin{array}{l}\text { Missio- } \\
\text { nário, } \\
\text { professor e } \\
\text { pesqui- } \\
\text { sador de } \\
\text { estudos do } \\
\text { Novo Testa- } \\
\text { mento. }\end{array}$ & $\begin{array}{c}\text { Megacódigo partidá- } \\
\text { rio da teoria da Nova } \\
\text { Escola, } \\
\text { apelativo, negligente, } \\
\text { falso, mentiroso e que } \\
\text { pretende obscurecer a } \\
\text { fé e a mensagem cristã. } \\
\text { O livro é quase não - } \\
\text { ficção, apesar de ser um } \\
\text { romance, a história é } \\
\text { um fato. }\end{array}$ \\
\hline $\begin{array}{l}\text { Revelando } \\
\text { o Código da } \\
\text { Vinci }\end{array}$ & $\mathbf{X}$ & & $\begin{array}{l}\text { Martin } \\
\text { Lunn }\end{array}$ & $\begin{array}{c}\text { Ms. em } \\
\text { História e } \\
\text { jornalística }\end{array}$ & $\begin{array}{l}\text { Mostrar a verdade por } \\
\text { trás da pesquisa de } \\
\text { Brown, separando a } \\
\text { realidade da ficção. }\end{array}$ \\
\hline $\begin{array}{l}\frac{\text { Rough Guide }}{\text {-O Código }} \\
\text { da Vinci: } \\
\text { História- } \\
\text { personagense } \\
\text { lugares }\end{array}$ & & $\mathbf{X}$ & $\begin{array}{l}\text { Michael } \\
\text { Verônica }\end{array}$ & & $\begin{array}{l}\text { O livro se julga mais } \\
\text { que ficção; Dan Brown } \\
\text { não é confiável, mani- } \\
\text { pula a verdade, escreve } \\
\text { bobagens históricas, } \\
\text { seu romance apresenta } \\
\text { sérias anomalias. }\end{array}$ \\
\hline
\end{tabular}

$O C D V$ foi intitulado pela maioria destes livros "cauda de cometa" de romance mentiroso por conter fatos, informações sobre documentos, obras de arte, sobre a Igreja Católica que não condizem com a verdade do mundo real. Embora a principal acusação seja relacionada à apresentação de muitos episódios e afirmações que dão a aparência de precisão factual, é provável que o incômodo do romance esteja centrado no fato de considerarem que Dan Brown, ainda em meio a construções meramente ficcionais, traz à tona hipóteses que põem em xeque o celibato de Jesus e a própria tradição do cristianismo.

Desde seu lançamento e conseqüentemente de seu sucesso de 
vendas, a narrativa em questão, é alvo constante de pareceres desfavoráveis, vindos destes livros. O livro não foi aprovado, uma vez que, desconsideram que $O C D V$ deve ser lido pelo que ele é: uma obra de ficção.

Para Ricardo Piglia, em Crítica y Ficción, publicado em 1986, não existe um lugar próprio para ficção, visto que tudo pode ser fictício. A própria realidade está tecida de ficções. Piglia assegura que embora a ficção trabalhe com a verdade, ela constrói um discurso que não é, e não pretende ser verdadeiro nem falso. É nesse ponto intermediário, duvidoso, onde se cruzam verdadeiro e falso que está todo o efeito, e a própria definição da ficção. A partir dessa assertiva, podemos considerar que $O C D V$ está situado nesse ponto intermediário, porque mesmo que algumas afirmações pareçam camuflar a natureza ficcional do livro, a ficção se anuncia. Ainda quando disfarçada, ela adverte que é disfarce.

A afirmação de que as descrições do romance correspondem à realidade, de certa forma dão credibilidade, mas para isso o leitor tem de levar a sério o que está lendo, só então poderá ter suas convicções abaladas por algo que é literatura de entretenimento, ficção.

A outra opção é que o leitor entre no jogo e entenda que um dos recursos de Dan Brown é brincar, jogar com a história, e desse modo, se esforça em apresentar tudo da maneira mais realista, ou melhor, mais verossímil possível. Brown ainda tem um forte argumento, antes mesmo desta declaração, lemos na contracapa de $O C D V$ a classificação: romance, ficção.

O corpus analisado supõem que Brown quer denunciar algo ou alguém, além de esquecerem que, se é ficção, o livro não erra, não mente, não mascara, não doutrina. Isso demonstra como esses pretensos críticos lêem de maneira confusa os textos que resenham.

A pretensão crítica nos livros que debateram e/ou bateram em $O C D V$ talvez se estabeleça, porque, de forma sintética, quando se fala em crítica, das reações de críticos a livros, a tendência é pensar naquilo que jornalistas ou quaisquer outras pessoas que escrevem ensaios, artigos, resenhas, publicam na mídia especializada, discutindo, recriminando, censurando ou elogiando.

Etimologicamente a palavra crítica origina-se do grego krimein, que significa separar, discernir, quebrar e de algum modo também influenciou na formação da palavra crise, ou seja, crítica é colocar algo em crise, colocar a obra em crise. Entretanto, assim como cada época 
tem a sua concepção de literatura, também a tem de crítica literária. Há mudanças inclusive no papel do crítico.

No livro La crítica literária del siglo XX: 50 modelos y su aplicación, Jaime Blume, Clemes Franken, passam pelas escolas e autorias mais representativas do século XX, analisando as diferentes correntes que disputam o direito de dizer suas verdades e explicam que seus principais compromissos com o texto literário são: “captar los distintos elementos que conforman; compreender lo que dichos elementos significan al interior del texto; valorar axiológicamente la obra como um todo" (BLUME \& FRANKEN, 2006. p. 13-14).

Terry Eagleton, em seu livro A função da crítica, publicado em 1991, em lugar de inventar uma nova função para a crítica, recorda que a função do crítico contemporâneo é o papel tradicional, ou seja, seu papel crucial é redescobrir de dentro das academias - lugar de sua legitimidade, seu centro vital - uma das suas funções tradicionais: quando ela não podia ser desvinculada da instituição da esfera pública ${ }^{91}$, e dialogava com a sociedade, com o leitor comum.

O autor levanta a questão de que a crítica atual perdeu toda a relevância social. "Ou faz parte do ramo de relações públicas da indústria literária, ou é uma questão interna as academias" (EAGLETON, 1991, p.1). Eagleton ressalta que a crítica está em crise, e ela ainda existe, porque ou essa crise ainda não foi registrada com suficiente profundidade ou está sendo ignorada.

Ao debatermos a função da crítica, não temos a intenção de cobrir o seu infinito campo, e, sim proporcionar alguns caminhos que nos levem a refletir que, se a própria crítica está em crise e tenta validarse a todo custo, é difícil definir se há crítica literária sobre $O C D V$. E, ainda, como classificar os livros que criticaram ou defenderam a referida narrativa?

Ainda segundo Eagleton, um crítico só pode escrever com segurança, enquanto a instituição crítica estiver acima de questionamentos. A partir daí surgem perguntas como: Qual o critério que o corpus analisado utiliza ao pretender criticar $O C D V$ ? Qual é o valor, a referência

91 Eagleton utiliza como conceito-chave de seu livro, o conceito de "esfera pública" burguesa, desenvolvido por Jürgen Habemas e que "abrange todo um domínio de instituições sociais - clubes, jornais, cafés, periódicos - nos quais os indivíduos se reúnem para o livre e eqüitativo intercâmbio de um discurso racional, consolidando-se, assim, em um corpo relativamente coeso, cuja deliberações podem assumir a forma de uma poderosa força política". 
utilizada? É o critério do vale tudo?

Para Roland Barthes, em Ensaios Críticos, 1982, a crítica ocupa um lugar intermediário entre a leitura e a ciência. Enquanto a leitura deseja a obra, a crítica deseja à sua linguagem, sua escritura; enquanto a leitura é imediata, a crítica é mediatizada por uma linguagem intermediária, que é a escritura do crítico. A crítica é discurso sobre um discurso, uma metalinguagem, cuja tarefa é descobrir validades e não verdades. Enquanto o objeto da ciência da literatura é a pluralidade dos sentidos da obra, ou seja, o sentido vazio que suporta todos os seus sentidos, a crítica literária dá sentido particular à obra. Enquanto a ciência trata dos sentidos, a crítica os produz, os duplica. Não o sentido da obra, mas o sentido daquilo que o crítico diz de tal obra, um sentido que se dá através da diferença e não por meio da repetição.

Ao escrever seu texto na década de 60, Barthes afirma que nos últimos anos a crítica pode ter caído no vazio, na tagarelice, na repetição daquilo que o texto já diz. Uma crítica feita somente de julgamento e que por esta razão não tem função na sociedade. No embate ao que é chamado de "velha crítica", o escritor francês propõe uma nova crítica, distanciada de concepções políticas e de sentimentos de valor; nela impera uma semiose infinita, em que a proposta é fazer análise e não interpretação, e uma análise sempre circunscrita dentro do texto, numa correspondência sempre textual. (BARTHES, 1982. p. 204).

Segundo Barthes a velha crítica não contradiz o que vem da tradição, da opinião corrente, onde objetividade, gosto e clareza são necessários ao se falar de um livro, levando esta fala a cair numa fala nula: tagarelice ou silêncio; existindo assim regras que ditam um verossímil crítico $^{92}$. O termo "verossímil crítico" acaba por contradizer a "verdade" buscada pela velha crítica e reafirma o pensamento de Barthes de que o trabalho da crítica não é encontrar "verdades", mas apenas "validades", o que corresponderia a uma verdade da linguagem, de uma linguagem possível, uma semiose.

Observa-se que há uma pretensão crítica nos livros que comentaram $O C D V$. Porém não há crítica. Pelo menos não a semiológica de uma análise inscrita no texto, numa correspondência sempre textual, problemas sempre de literatura, mas a pretensão da crítica historicista, tagarela, que repete aquilo que o texto já disse, a crítica do vale tudo, crítica que se propõe à interpretação, a relacionar verdade e mentira, a

92 Segundo Aristóteles, o verossímel crítico corresponde ao que o público acredita possível e que pode ser bem diferente do real histórico ou do possível cientifico. 
Bíblia e $O C D V$, Deus e Brown, Teologia e Literatura.

Na própria etimologia da palavra e no sentido barthesiano: critica é pôr em crise, e não julgar. As duas categorias analisadas, com pretensão crítica, o que mais fazem é julgar, não buscam validades, pelo contrário, se apresentam obcecadas pela verdade, segundo eles, ferida pelo romance. Tanto os moderados quanto os radicais, confirmam a hipótese desta pesquisa de que os livros "debatedores" de $O C D V$ confundem o que é Teologia e Literatura em $O C D V$.

Essa avaliação subjetiva, não apresenta descrição de aspectos objetivos que dêem sustentação a seus argumentos. Eles apropriam-se de $O C D V$ sob pretexto de explicar, decodificar, desmascarar, advertir, dar autos-de-fé, quebrar o romance, querem a todo custo expor Dan Brown ao descrédito. De forma amadorística, a maioria deles analisa fato e ficção em pé de igualdade e refletem apenas uma opinião, um gosto pessoal, uma convicção religiosa, ou o desejo de na esteira do sucesso do Código, transformarem-se na cauda do cometa, obter um lucro sórdido, dizendo qualquer coisa para conquistar sua fatia no mercado. Este é o melhor adjetivo para estes livros aqui analisados: cauda de cometa. 


\section{Referências}

ADABÍA, José Pedro. A Bíblia como Literatura. Petrópolis: Vozes, 2000.

ABANES, Richard. A verdade por trás de O Código Da Vinci: uma resposta desafiadora à ficção mais vendida. Trad. Thais $M$. S. da Silva Amadio. São Paulo: Celebris, 2005.

BARTHES, Roland. Crítica e verdade. Trad. Leyla Perrone-Moisés. São Paulo: Ed. Perspectiva, 2000.

. Ensaios Críticos. Trad. Leyla Perrone-Moisés. São

Paulo: Ed. Perspectiva, 1982.

BLUME, Jaime, FRANKEN, Clemens. La crítica literaria del siglo XX: 50 modelos y su aplicación. Santiago: Ediciones Universidad Católica, 2006.

BOCK, Darrell L. Quebrando o Código Da Vinci: respostas às perguntas que todos estão fazendo. Trad. Eduardo Rado. Osasco: Novo Século, 2004.

BROWN, Dan. O código Da Vinci. Trad. Celina Cavalcante. Rio de Janeiro: Sextante, 2003.

BUENO, Lorenzo \& URRESTI, Mariano. As chaves do Código Da Vinci: A descendência secreta de Jesus e outros mistérios. Trad. Amilton Lovato e Monalisa Neves. São Paulo: Companhia dos Livros, 2004.

BURSTEIN, Dan. Os Segredos do Código. Trad. Carlos Irineu da Costa, Cláudio Figueiredo e Pedro Jorgensen Jr. Rio de Janeiro: Sextante, 2004.

COX, Simon. Decifrando o Código Da Vinci: os fatos por trás da ficção. Trad. Claudia Gerpe Duarte. Rio de Janeiro: Bertrand Brasil, 2005. 
EAGLETON, Terry. A função da Crítica. Trad. Jefferson Luiz Camargo. São Paulo: Martins Fontes, 1991.

. Teoria da Literatura: Uma Introdução. Trad. Waltensir Dutra. São Paulo: Martins Fontes, 2006.

GARLOW, J \& JONES, P. Desmascarando o Código da Vinci. Curitiba:A. D. Santos Editora LTDA, 2004.

HAAG, Michael \& HAAG, Verônica. O Código Da Vinci -História - personagens e lugares. São Paulo: Publifolha, 2004.

LUNN, Martin. Revelando o Código Da Vinci. Trad. Milena Soares Carvalho. São Paulo: Madras, 2005.

LUTZER, Erwin. A fraude do Código Da Vinci: toda a verdade sobre a ficção do momento. Trad. James Monteiro dos Reis. São Paulo: Vida, 2004.

PIGLIA, Ricardo. Crítica y Ficción. Cuaderno de extensión Universitaria, n. 9, serie Ensayo, Universidad Nacional del Litoral, Argentina, 1986.

WELBORN, Amy. Decodificando Da Vinci: os fatos por trás da ficção de O Código Da Vinci. Trad. Rosane Albert. São Paulo: Cultrix, 2004. 